\title{
Breast Pleomorphic Adenoma
}

National Cancer Institute

\section{Source}

National Cancer Institute. Breast Pleomorphic Adenoma. NCI Thesaurus. Code C40408.

A rare, benign and well circumscribed neoplasm that arises from the breast. It is

characterized by the proliferation of epithelial and myoepithelial cells surrounded by chondroid stroma. 